\title{
Contingency and construction: from mimesis to postmodernism
}

\author{
Peter V. Zima \\ Institute of General \& \\ Comparative Literature \\ University of Klagenfurt \\ KLAGENFURT \\ Austria
}

\begin{abstract}
Contingency and construction: from mimesis to postmodernism

In this article the transition from literary realism (Balzac, George Eliot, Verga) is described as a shift from mimesis to constructivism. It is indicated how the realist confidence in the ability of the writer to represent reality as such yields to a modernist skepticism which recognises the contingent character of all fictional constructs. In spite of this discovery, modernists such as Kafka, Proust and Sartre still believe in a meaningful search for reality, authenticity and truth. This belief seems to disappear in the works of postmodernist authors such as Robbe-Grillet, Eco or Fowles who tend to dissociate fiction from any kind of meaningful search, transforning it into a game: a gadget for the reader. The author, who adopts the perspective of Critical Theory, argues towards the end of the article that the latter is modernist insofar as it refuses to follow the postmodernists in their playful abandoning of key realist and modernist concepts such as truth, authenticity and critique.
\end{abstract}

\section{Introduction}

Like many other historical titles which announce a narrative presentation of facts - e.g. "From Baudelaire to Surrealism", "From Hegel to Marx" - the title of this article suggests that it develops one of those metanarratives or métarécits which Lyotard so eloquently warns us against. There is no point in denying this. It is good to know, however, that Lyotard himself narrates why grand metanarratives meet with increasing incredulity in what he calls the postmodern era. It therefore seems that it is well-nigh impossible to engage in theoretical discourse without producing narrative sequences of varying lengths. This insight need not have a discouraging or daunting effect upon us; on the contrary, it should encourage us to put our cards on the table and to present our analyses and explanations as contingent constructions, not as representations of reality as it is in itself. 
In the age of Radical Constructivism and Deconstruction this idea - that our knowledge is not a representation but a construction of reality - may seem trivial or banal because it has been accepted by most of us. Indeed, as I shall try to show in the course of this narrative, it has become a commonplace of modern and postmodern literature, of fiction. My central argument is that this was not always the case, because in the past, certainly in the first half of the 19th century many philosophers and realist writers believed or tacitly assumed that their discourses actually represented reality and truth. Only modernist and postmodemist philosophy and literature began to systematically challenge this "representational", "realist" or "mimetic" point of view and to ask how theoretical or fictional constructions of reality came about. In other words, the transition from realism to modernism - both in the chronological and the theoretical (epistemological) sense - is a shift from representation or mimesis to construction or semiosis. It is the aim of this article to describe this shift and to evaluate it in a conclusory remark on Critical Theory.

The central idea is commented on by Michael Ryan in an essay on "Postmodern Politics", where the "theory of representation" is attributed to modernism and criticised from a postmodern point of view: "One of the central objects of critique in postmodern philosophy", Ryan argues, "is the classical theory of representation, which held that meaning or truth preceded and determined the representations that communicated it" (Ryan, 1988:559). I shall attempt to show that this is a simplification insofar as modernist philosophy and literature inaugurated a radical critique of what might be called "the representational fallacy" long before postmodernism was en vogue. One of the major differences between modernism and postmodernism, I shall argue, is the fact that whereas modernists such as Proust, Sartre and Kafka believed in the existence of a possibly inaccessible - reality and truth, postmodernists such as Robbe-Grillet, Lyotard or John Barth discard the latter as metaphysical concepts.

\section{The "representational fallacy": realism and mimesis}

Let me begin with the approach which I have called "the representational fallacy". Someone who has studied the discourse of historians and compared it to the discourse of fiction may very well ask at this point whether anyone ever believed in representation or mimesis. He may remind us of the fact that even a 17th century philosopher such as François La Mothe had a lot to say about the problem of subjectivity and of subjective bias in historiography. What would our image of the Punic wars be today, he asked, if only we had access to an account from the point of view of the Cartheginians as well as that of the Romans? How would Caesar's Gallic wars now appear if Vercingetorix had been the one to write his Commentaries? In a similar fashion the German 18th century scholar J.M. Chladenius pointed out that: "We cannot avoid looking at history each from 
his own point of view, and therefore retelling the story according to that point of view (...)" (Chladenius, 1752:150). One would merely have to add with Luis Prieto, a contemporary semiotician, that it is the point of view which engenders the object, in order to open up a radically constructivist perspective. Hence the question remains whether anyone ever genuinely believed in representation. If historians were so cautious and circumspect, one might wish to add, it seems quite likely that philosophers and novelists would be even more skeptical.

This is of course the case and it would be a gross simplification to argue that a reputed realist like Balzac naively believed in the fictional representation of reality. Nevertheless, his well-known preface to La Comédie humaine contains at least two ideas which foster the realist or representational illusion (which according to Macherey is a product of the author's realist ideology): the first idea is an analogy postulated by Balzac between natural science (i.e. Buffon's zoology) and the discourse of the novel; the second idea is that of a truthful representation. The novelist, Balzac argues, studies society in very much the same way as the zoologist studies the animal species, although the complexity of the social order makes the historical and social novel a formidable task. Like natural scientists of the 19th century Balzac thinks that the subject's main task is to let the facts speak for themselves: "French society would be the historian, I should merely be its secretary" ("La société française allait être l'historien, je ne devais être que le secrétaire" - Balzac, 1965:52). Balzac is quite specific about the task of the writer as a secretary of history: "Following the principle of this rigorous reproduction, a writer could become a more or less faithful, more or less fortunate, patient or courageous painter of human types, narrator of intimate human dramas, archeologist of the social edifice, classifier of professions, registrator of good and evil (...)."

(S'en tenant à cette reproduction rigoureuse, un écrivain pouvait devenir un peintre plus ou moins fidẻle, plus ou moins heureux, patient ou courageux des types humains, le conteur des drames de la vie intime, l'archèologue du mobilier social, le nomenclateur des professions, l'enregistreur du bien et du mal (...) - Balzac, 1965:52.)

Expressions such as "rigorous reproduction" and "a more or less faithful painter" suggest that Balzac must have been quite fond of creating a realist illusion - for he was well aware of writing fiction and not history.

In spite of this awareness, he may even have believed, at least temporarily, in the illusions engendered by his own fiction. His letter to Monsieur Gavault which serves as a preface to Les Paysans reveals to what extent Balzac was attached to the idea of representation or, as he puts it himself, "reproduction": "I study the movement of my time and I publish this work" ("J'étudie la marche de mon époque, et je publie cet ouvrage" - Balzac, 1968:19). In fact he calls his novel a 
"study" ("cette ètude"), thereby establishing a vital link between representation and truth. We shall see that from a modernist point of view both concepts appear to be highly problematical.

Very much like Balzac who intended to be a faithful painter of his society, George Eliot believed in the ideal of representation which in the famous 17th chapter of Adam Bede she illustrates by the metaphors of reflection and of the mirror:

Certainly I could, my fair critic, if I were a clever novelist, not obliged to creep servilely after nature and fact, but able to present things as they never have been and never will be (...). But you must have perceived long ago that I have no such lofty vocation, and that I aspire to give no more than a faithful account of men and things as they have mirrored themselves in my mind. The mirror is doubtless defective; the outlines will sometimes be disturbed; the reflection faint or confused; but I feel as much bound to tell you, as precisely as I can, what that reflection is, as if I were in the witnessbox narrating my experience on oath (Eliot, 1985:221).

Like the French realist, George Eliot intends to be faithful to facts, thereby hoping to reveal the truth. Paraphrasing Balzac, one could say that she promises to be a faithful secretary of reality, letting facts speak for themselves.

This attempt to efface or obliterate the role of the writing or narrating subject is also characteristic of the Italian Verismo, in particular of Giovanni Verga who started as a romantic (influenced by the Scapigliatura milanese) but later on became a realist, replacing the search for beauty by the search for truth. His introduction to L'Amante di Gramigna is not only reminiscent of Balzac and Eliot but combines the main themes of realism - representation, scientific aspirations, the search for truth, and the obliteration of the subject - in one compact paragraph. Having characterised his literary project as a "science of the human heart" ("scienza del cuore umano"), Verga writes that "the artist's hand will remain absolutely invisible, so that the work of art will bear the imprint of the real event and will appear as having produced itself, as having matured and spontaneously sprung forth like a natural event, without any contact with its author, without any trace of the original sin".

(... che la mano dell'artista rimarrà assolutamente invisibile, allora avrà l'impronta dell'avvenimento reale, l'opera d'arte sembrerà essersi fatta da $s \grave{e}$, aver maturato ed esser sorta spontanea come un fatto naturale, senza serbare alcun punto di contatto col suo autore, alcuna macchia del peccato d'origine - Verga, 1973:361.)

This passage is extremely rich in ideas and can be read as a summary or manifesto of realism or verism: 
- First of all, there is the attempt to keep the process of creation or construction secret ("che la mano dell'artista rimarrà assolutamente invisibile", i.e. identify literary discourse and reality).

- The scientific aspirations and the obliteration of the subject become manifest when Verga emphasises the natural character of the work of art and the invisibility of the artist's hand.

- The search for truth is expressed by the words "la sincerita della sua realtà" ("the sincerity of its reality")

- Moreover, Verga adds another important element to the realist creed: necessity as inevitable concatenation of words, acts or events ("il suo modo $\mathrm{e}$ la sua ragione così nesessarie”).

We shall see that in modernism the notion of necessity will be replaced by that of contingency which gives birth to a constructivist consciousness.

Although the German philosopher Hegel cannot be considered an exponent of literary realism, especially since his ideal was the classical art of Greek antiquity, he is certainly a philosophical realist: someone who actually believes that his discourse corresponds to social and historical facts and that, conversely, these facts are made intelligible by his discourse. In other words: he postulates an identity between thought and discourse. In this respect John E. Smith (1974:118) is correct when he concludes: "Hegel was, in this regard, a thoroughgoing realist: what we know is the things themselves, their properties, unities, relations. For Hegel, the real is not 'behind' or 'beyond', but actually present in what we apprehend." In other words: facts speak for themselves and the philosopher, in assuming their "speech", articulates reality itself. All this of course contrasts with Kant's idea that we can never obtain knowledge of things as they are, because our perception is subjective, i.e. inextricably tied up with the categories of space and time.

Hegel's realist belief that philosophical discourse and reality are one was, however, later on - in the middle of the 19th century - challenged by one of his disciples - Friedrich Theodor Vischer - who, although a Hegelian in most respects, could no longer believe in the identity of subject and object, of discourse and reality. Vischer's critique of his master is important in two respects: firstly, because it announces the skeptical stance of modernism; secondly, because it announces some of the most important discoveries of modemism such as contingency, constructivism, the subjectivity of reason, and the dream. 
He (Hegel) believes that in his world-reason he has linked nature to conceptual thought, but he has failed to explain their apparently absolute antagonism, their separation, the 'alterity' in relation to the idea; and because this alterity has not been accounted for, they all fall apart, and the fullness of essence which exists in his idea of world reason is no more than his own sincere idea. If then nature has not really been derived, chance which goes with it, has not been derived either, and that explains why Hegel deals with chance on the natural side of spirit, i.e. with the dream, quite scathingly and peremptorily, like with all things which are due to chance (Vischer, 1922:482).

Hegel may have thought that philosophical discourse represents and contains reality and that nature can be derived from spirit, from thought. He was mistaken, however, says Vischer, anticipating Adorno, because he has subsumed alterity (or otherness) under his thought without really integrating it into his system, without having understood it. Now alterity breaks out of the philosophical system and its parts, its mebra disiecta lie scattered before our eyes. This is the scene of modernism, of modernist philosophy, art and literature which Vischer announces in his critique.

\section{Modernism and construction}

Modernism can be said to begin with the disintegration of the realist illusion, of the "representational fallacy". Unlike Hegel, Nietzsche, possibly the most important precursor of modernism and postmodemism, no longer believes that philosophical and literary discourse represents or contains reality. In his view, the philosopher and the artist shape and construct reality, and consequently art is defined by him as "the will to create appearance", "als der gute Wille zum Scheine" (Nietzsche, 1980:113). In this context, Jean-Paul Sartre seems to resume and to continue Friedrich Theodor Vischer's critique when, in an article on the philosophy of Kierkegaard, he reveals the contingency of the Hegelian system, rejecting its claim to represent reality, to be real, essential and true. Sartre points out: "From this point of view, the origin of the Hegelian system is not Being but Hegel's person: as it was made, as it made itself. An ambiguous discovery which, from the point of view of Knowledge, can only lead to skepticism."

(De ce point de vue, au commencement du système hégélien, il n'y a point l'être mais la personne de Hegel, telle qu'on l'a faite, telle qu'elle s'est faite. Découverte ambigue qui, du point de vue du Savoir, ne peut conduire qu'au scepticisme - Sartre, 1966:39.)

In other words: Hegel's philosophy is not objective or a true representation of reality or reality itself; it is - as Vischer had already suggested - a subjective 
construction, inseparable from the philosopher as a historical individual. The skepticism Sartre refers to is the skepticism of modernism as a whole. This skepticism, however, is embedded in a search for truth and reality which is common to authors who, considered from a different point of view, might appear to be miles apart: Franz Kafka, Robert Musil, Marcel Proust, Luigi Pirandello and - Jean-Paul Sartre.

The beginning of Kafka's novel The Trial has nothing realistic about it in the sense of Balzac, George Eliot or the Italian Verismo: nothing is explained to the protagonist and the reader, because the numerous explanations which are provided merely increase the already existing confusion. Reality and truth are neither given at the outset nor found at the end; they are replaced by an unending search for reality and truth. At the end of the day, neither the protagonist nor the reader are in a position to answer the crucial questions: What is reality? What is the law? and: What is truth? In one of the final or possibly not quite final scenes (the novel is after all a fragment), the parable Before the low can be read as a metonymic image of reality which is endlessly constructed and reconstructed by the protagonist $\mathrm{K}$. and his interlocutor, the priest. Each construction, however, appears to be contingent, governed by chance, by an inadequate interpretation or by a flaw in the argument. None of the constructions is necessary, i.e representative of the real in the sense of Hegel or Verga.

There is a scene in Marcel Proust's A la Recherche du temps perdu which also reminds us of the epistemological impossibility of an adequate, that is to say: realistic, truthful or "veristic" reproduction of the world. Marcel, the narrator, is desperately trying to find out the truth about his girlfriend Albertine, who is one of the most ambivalent characters of the novel. It is by sheer chance that he finds out, in the course of one of their unrewarding conversations, that she knows Léa after all, Léa whom he considers to be a lesbian: "I was wrong to hide from you a three week journey with Léa. But I hardly knew you then. - Was it before Balbec? (asks the narrator) - Before the second, yes. And that very morning she had told me that she didn't know Léa! I saw a flame burning in the nick of time a novel which took me millions of minutes to write."

(J'ai eu tort de vous cacher un voyage de trois semaines avec Léa. Mais je vous connaissais si peu. - C'était avant Balbec? (asks the narrator) Avant le second, oui. Et le matin même, elle m'avait dit qu'elle ne connaissait pas Léa! Je regardais une flambée brûler d'un seul coup un roman que j'avais mis des millions de minutes à écrire - Proust, 1954:350.)

As in Kafka's case, it is impossible to make reality transparent and accessible: each attempt to approach it is vitiated by random revelations or other contingent facts. The modernist author nevertheless perseveres in his search for truth, for the essence behind fleeting appearances. In this respect he is still a disciple of 
Hegel: he has ceased to be a Hegelian, however, insofar as he is well aware of the fact that his notion of reality is a contingent construction which is ever so fragile. Instead of exclaiming "que $j$ 'avais mis des millions de minutes à écrire", Proust's narrator could have said: "que j'avais mis des millions de minutes à construire".

In the modernist text, it is not only difficult or impossible for me to get to know the Other ("alterity", as Vischer says), it is as difficult to know myself. The inability of the subject to know and define himself is the main topic of another modernist novel: of Luigi Pirandello's Uno, nessuno e centomila. As in Proust's case, chance, which Hegel was determined to exclude from his system, causes the hero's perception or construction of reality, and in particular of himself, to collapse. His wife's casual remark that he has an uneven nose, reveals to him that he is a stranger to himself, since other people's perception of him does not seem to correspond to his own. The narrator-hero discovers "the stranger inseparable from myself" ("l'estraneo inseparabile da me") (Pirandello, 1985:20).

It would be a mistake to assume that Pirandello's novel is simply about the stranger within ourselves. Its scope stretches well beyond this existential discovery - which in itself is revolutionary enough. It anticipates in many respects Radical Constructivism (Maturana's Varela's and Glasersfeld's theories) by making us realise that reality as we know it is our construct and that we know reality only inasmuch as it is our construct. If we leave the city in order to go out into the open country, we realise, the narrator says, that the reality we know is our own construction: "Starting from the simple fact that we have by now left the city, that is, a constructed world ..." ("Dal semplicissimo fatto che siamo usciti or ora dalla città, cioè, si, da un mondo costruito ...") (Pirandello, 1985:53). Once we have left our constructions, however, we may very well come to recognize their contingency, their emptiness and inanity: “... di cui riconoscete l'affligente vanità", says the narrator, ("the terrible vanity of which you recognise" Pirandello, 1985:53-54). The verb "to construct" ("costruire") is certainly one of the most frequent lexical units in Pirandello's novel: "I construct myself continuously and I construct you and you do the same." ("Io mi costruisco di continuo e vi costruisco, e voi fatte altrettanto" - Pirandello, 1985:60). This means that we can only construct reality without any hope of being able to approach it directly, without mediation. It also means that the Subject - as G.H. Mead very well knew - is our own construction and the construction of others, which evolves in the course of interaction.

The consequences of this insight for modemist philosophy and literature are enormous and could be dealt with in several volumes. I propose to comment on only one aspect of this problem: the constitution of subjectivity and the 
relationship between subjectivity and contingency in Proust's Recherche and Sartre's la Nausée. In both cases, reality as such - Paris society in the case of Proust and Bouville existence in the case of Sartre - is incomprehensible and meaningless.

Proust's narrator Marcel who, as we know, cannot make sense of the real world as it appears to him. The problem seems to be that this world is not differentiated: "Inasmuch as the world of differences does not exist on the surface of the earth, among all the countries which our perception unifies, it certainly did not exist in the 'world'. Does it actually exist anywhere? Vinteuil's septuor seemed to say yes. But where?"

(Le monde des différences n'existant pas à la surface de la terre parmi tous les pays que notre perception uniformise, à plus forte raison n'existe-t-il pas dans le 'monde'. Existe-t-il, d'ailleurs, quelque part? Le septuor de Vinteuil avait semblé me dire que oui. Mais où? - Proust, 1954:277.)

The expression "the world of differences" ("le monde des différences") is particularly important here, because it refers to the classification or taxonomy envisaged by the narrator, the speaking subject. The taxonomy or "le faire taxinomique", as Greimas would say, constitutes the basis of subjectivity and its constructions. This is what Roland Barthes meant by his bon mot: "Dis-moi comment tu classes, je te dirai qui tu es." ("Tell me how you classify and I'll tell you who you are.")

In Proust's case, as is well known, the entire classification or taxonomy rests upon the difference between art and society or, to be more precise, literature and conversation. In Le Temps retrouvé the word différence appears again at a stage when the construction of the subject, the Self and its reality is almost accomplished. For the narrator, literary style becomes a revelation: "It is the revelation, which would be impossible to acquire by direct and conscious means, of the qualitative difference in our perception of the world, a difference which would remain the eternal secret of each of us, if art did not exist."

(Il est la révélation, qui serait impossible par des moyens directs et conscients, de la différence qualitative qu'il y a dans la façon dont nous apparaît le monde, différence qui, s'il n'y avait pas l'art, resterait le secret éternel de chacun - Proust, 1954:895.)

It is hardly necessary to add that at this point the discovery of art coincides with the discovery of truth and the constitution of the subject as an artist.

The process of construction is even more pronounced, more consciously reflected in La Nausée. At the very beginning of the novel, Roquentin, the narrator, decides to classify the small facts of daily life: “... même s'ils n'ont l'air de rien, 
et surtout les classer" (Sartre, 1981:5). Much later, towards the end of the novel, he establishes a clear distinction between unstructured and meaningless reality which he calls existence and the world of our constructions and signs: "... The world of explanations and reasons is not that of existence. A circle is not absurd, it can be very well explained by the rotation of a straight line around one of its extremities. But a circle does not exist. This root, however, did exist in the sense that I could not explain it."

(... Le monde des explications et des raisons n'est pas celui de l'existence. Un cercle n'est pas absurde, il s'explique très bien par la rotation d'un segment de droite autour d'une de ses extrémités. Mais aussi un cercle n'existe pas. Cette racine, au contraire, existait dans la mesure où je ne pouvais pas l'expliquer - Sartre, 1981:153.)

Like Pirandello's novel this passage reminds us of the central thesis of Radical Constructivism: we can only understand and explain what we have ourselves constructed.

Like Proust's Marcel, whom he is supposed to parody, Sartre's Antoine Roquentin finds or rather invents his own world of differences: "And at this very moment, on the other side of existence, in that other world which one can discern in the distance without ever being able to approach it, a little melody began to dance, to sing..."

(Et à ce moment précis, de l'autre côté de l'existence, dans cet autre monde qu'on peut voir de loin, mais sans jamais l'approcher une petite mélodie s'est mise à danser, à chanter ... - Sartre, 1981:207.)

The end is quite similar to that of Proust's Recherche: "However, the moment would come when the book would be written, would be behind me and I think that then some light would be shed on my past". ("Mais il viendrait bien un moment où le livre serait écrit, serait derriẻre moi et je pense qu'un peu de clarté tomberait sur mon passé" - Sartre, 1981:210). - Once again the construction of reality coincides with the construction of the subject, the containment of contingency and the invention of truth.

The crucial difference between realism and modernism appears to reside in the latter's claim that reality and truth are our constructions and hence not to be confused with what is generally called the real world. In other words: our reality is a fiction in very much the same way as Sartre's, Proust's and Pirandello's reality is. This is what another modernist, Miguel de Unamuno meant, when in a preface to his novel Niebla he wrote: "A world of fiction? A world of reality? Of real fiction which is fiction of reality." ("¿Ente de ficción? ¿Ente de realidad? 
De realidad de ficción que es ficción de realidad" - Unamuno, 1978:20.) The reality of fiction: this is a postmodern idea par excellence.

\section{Postmodernism: Construction without truth}

The distinctive features of postmodernist fiction have been discussed during the last few decades and we all remember Ihab Hassan's list of criteria, some of which also seem to apply to modernism. One salient feature of postmodernism which distinguishes it from modernist art and literature seems to be its break with the quest for truth. Like modernist writers, their postmodernist successors no longer believe in the possibility of a truthful representation of reality: they are constructivists and their constructivism is even more pronounced, more radical than Sartre's or Pirandello's. However, they no longer seem to associate their constructions with a search for religious, existential, political or aesthetic truth. They engage in daring aesthetic experiments without any metaphysical or aestheticist pretensions.

John Barth's Lost in the Funhouse (1988) is a case in point: it can be read among other things - as an intertextual reaction to the artist novel which is reflected upon and parodied. Like some of the modernists, Barth turns writing into one of the central themes of his text: like Sartre and Pirandello he comments on his own constructions and in fact uses the verb to construct when, at the end of his text, he ponders on the future of Ambrose, the hero artist: "He wishes he had never entered the funhouse. But he has. Then he wishes he were dead. But he's not. Therefore he will construct funhouses for others and be their secret operator - though he would rather be among the lovers for whom funhouses are designed" (Barth, 1988:97). The artist may continue to be an outsider like Tonio Kröger or Antoine Roquentin but he no longer appears as a guardian of truth: he has definitely lost his aureol and his aura, as Baudelaire and Walter Benjamin would say.

Barth's idea that fiction is a funhouse constructed by the artist is taken seriously by Italo Calvino who begins his novel Se una notte d'inverno un viaggiatore by referring explicitly to the funhouse (and it certainly is one) he is about to construct: "You are about to begin the new novel by Italo Calvino Se una notte d'inverno un viaggiatore. Relax." ("Stai per cominciare a leggere il nuovo romanzo Se una notte d'inverno un viaggiatore di Italo Calvino. Rilassati" Calvino, 1979:3.) This novel is certainly an exciting experiment and an aesthetic adventure, but Proust's and the young Sartre's aesthetic quest for truth has completely vanished.

An analogous case is Alain Robbe-Grillets Dans le labyrinthe which can be read as a quest without an end and without an object; it is above all a manifesto 
written against the realist or representational illusion: "This story is fiction, not a testimony". ("Ce récit est une fiction, non un tèmoignage" - Robbe-Grillet, 1959:7.) Several lines further, Robbe-Grillet adds in his preface to the novel: "This is, however, a purely material reality, which means that it does not pretend to be of allegorical value." ("Il s'agit pourtant ici d'une réalité strictement matérielle, c'est-à-dire qu'elle ne prétend à aucune valeur allégorique” - RobbeGrillet, 1959:7.)

We have travelled a long way from Balzac's notion of representation and Giovanni Verga's ideas about objectivity. The Nouveau Romancier wants his text to be read as a construction of polysemic signs, not as an allegory of the real (i.e. in a mimetic way).

In Robbe-Grillet's novel, only constructions exist, and these constructions do not seem to yield any results, do not seem to lead anywhere. "But this scene leads nowhere" ("Mais cette scène ne mène à rien" - Robbe-Grillet, 1959:179), remarks the narrator interrupting his own discourse and starting from scratch. Reality of course is perceived as always, but its very perception makes it incomprehensible: "The soldier sitting at the last table but one at the back, on the right, has certainly a more realistic view of the battle; this is why he has nothing to say about it (...)"

(Le soldat, assis à l'avant-dernière table, dans le fond a droite, possède certainement une vue plus réaliste des combats; aussi n'a-t-il rien à dire à leur sujet (...) - Robbe-Grillet, 1959:217-218.)

This seems to be the final paradox of the Nouveau Roman: the more we see of reality, the more we know about it, the less we have to say. This is indeed Hegel standing on his head.

In this context is is hardly surprising that, looking back on the first phase of the Nouveau Roman, Maurice Roche considers Butor's, Robbe-Grillet's and Claude Simon's texts as "literary gadgets" ("gadgets littéraires") as "meticulous and useless machines" ("machines précises et inutiles" - Roche, 1966:168) which neither depict nor criticise contemporary social reality. Unlike the great novels of realism and modemism which were meant to fulfil an oppositional, critical and in some cases even utopian function, the Nouveau Roman and its successor, the Nouveau Nouveau Roman, do not pretend to be more than playful experiments which have once and for all renounced the metaphysical quest for truth.

The only truth which the postmodern avant-gardes of the sixties and seventies admit is the "truth of the game": "Not the truth guides my hand, but the game, the truth of the game." ("La vérité ne guide pas ma main, mais le jeu, la vérité du jeu" - Barthes, 1971:169.) This is a Nietzschean way of saying that truth in the 
platonic, metaphysical sense dies a natural death, once its linguistic, its rhetorical foundations are revealed. This is undoubtedly why, in Sade, Fourier, Loyola (1971), Barthes considers these three thinkers not so much as theoreticians of sexuality, society or religion, but as "founders of language" ("fondateurs de langue" - Barthes, 1971:11). The rhetorical "gadget" or "machine" of sexual, social or religious classification seems to matter more in this particular case than the ideas or truths expressed.

In conjunction with this Nietzschean conception of discourse which reduces the latter to its formal and rhetorical dimensions, it would be possible to consider postmodern novels as playful experiments with new or traditional forms: as linguistic and generic games which tend to transform the metaphysical constructions of modernism (such as Mallarmé's negativity, Proust's and Sartre's art and Musil's utopia of essayism) into "gadgets" in the sense of Maurice Roche.

This transformation of the modernist metaphysical quest into a postmodern "game" or "gadget" is not only one of the salient features of the experimental Nouveau Roman or of Italo Calvino's reader-response-oriented text, but also characterises the more popular postmodern novels such as John Fowles' The French Lieutenant's Woman or Umberto Eco's Il nome della rosa. In both cases, the experimental elements have been divested of their metaphysical (i.e. religious, revolutionary or aestheticist) connotations and integrated into the conventional structure of a readable text.

The following passage from Fowles' novel shows to what extent the essayist experiment which Musil used to explore the utopian dimension of language and narrative has been absorbed by a postmodern convention which no longer pretends to go beyond the established literary or social order:

I do not know. This story I am telling is all imagination. These characters I create never existed outside my own mind. If I have pretended until now to know my character's minds and innermost thoughts, it is because I am writing in (...) a convention universally accepted at the time of my story: that the novelist stands next to God. He may not know all, yet he tries to pretend that he does. But I live in the age of Alain Robbe-Grillet and Roland Barthes; if this is a novel, it cannot be a novel in the modern sense of the word. - So perhaps I am writing a transposed autobiography; perhaps I now live in one of the houses I have brought into the fiction; perhaps Charles is myself disguised. Perhaps it is only a game (Fowles, 1992:85).

This passage could be read as a concise presentation of the postmodern literary scene: as postmodernism in a nutshell. From the very outset literary discourse is 
regarded as a contingent construction or conjecture which entirely depends on the particular viewpoint of an individual subject. At the same time, the realist and mimetic pretensions of the 19th century omniscient narrator are rejected with an ironic gesture: "He may not know all, yet he tries to pretend that he does". In this context Balzac's and George Eliot's aspirations towards a "rigoureuse réproduction" and "a faithful account of men and things" appear as illusions of realism which modernist constructivists polemically deconstruct and postmodern constructivists view with nostalgic playfulness. In the end, the author-narrator self-consciously transgresses the generic limits of the novel and, admitting his indebtedness to Robbe-Grillet and Roland Barthes, conludes: "Perhaps it is only a game."

As a matter of fact, Fowles' The French Lieutentant's Woman is only a game: a discursive, generic game with the form of the Victorian novel, with the literary past which Eco, the postmodernist, would like to revisit "with irony and without innocence" ("con ironia, in modo non innocente" - Eco, 1980:529). According to Eco, the avant-garde was wrong in trying to destroy past literary forms: at the end of the day, he argues, it ran out of inspiration precisely because it despised and demolished the very conventions on which it thrived.

However, a return to the past (to past literary forms) cannot be a return with devotion and fervour; it can only be a revival with ironical undertones, without metaphysical connotations. This is very much Fowles' attitude: he returns to the Victorian novel not in order to resurrect it but to transform it into a "game", into a "gadget" in the sense of Maurice Roche. At the same time he deprives it of its sociocritical dimension and of its quest for truth which was crucial to a modernist novel like Kafka's The Trial or Proust's Recherche.

\section{Critical theory between modernism and postmodernism: conclusion}

As a critique of Hegel's "identifying thought", of his "Identitätsanspruch" (Adorno, 1966:24), Adorno's and Horkheimer's Critical Theory, which underlies the central argument of this article, is both constructivist and modernist. One might say that it is constructivist avant la lettre because it is modernist. Its constructivism is of Kantian origin and is very much opposed to Hegel's "realist" postulate that (Hegelian) philosophical discourse and reality coincide. In Negative Dialektik (1966) Adorno argues with Kant - and against Hegel - that subject and object cannot be identified given the fact that the categories of subjective thought never correspond with the objective world. Any attempt to deduce the latter from the former amounts to a dangerous tour de force in which both are annihilated. In other words: there cannot be a "rigorous reproduction of 
reality" by human thought, by a mode of being inevitably tinted by the particular, the contingent.

In order to take into account the contingent character of our subjectivity and discourse, in order to avoid the violent assimilation of the object to the subject, Adorno tried to develop modes of thought and discursive forms which might be called constructivist. Like Robert Musil, he adopted the fragmentary perspective of the essay, hoping to do justice to the particular feature and the individual being, both of which were threatened by the streamlining effects of the (Comtian, Hegelian) system. In order to counter these effects, Adorno devised a thought geared towards the particular model ("in Modellen denken" - Adorno, 1966:37) which at one time he considered as the best way of approaching reality without reducing its particularities to the abstractions of the subjective concept. Eventually, he decided to abandon the idea of the model and replaced it by parataxis: by a paratactic (i.e. non-hypotactic, non-hierarchical) way of writing which he developed in his posthumously published Ästhetische Theorie (1970).

Although these constructivist modes - the essay, the model, the paratactic composition - imply a rejection of the realist idea of mimetic correspondence, they depart radically from the postmodernist game: unlike postmodernist writers and philosophers, unlike Fowles or Rorty, Adorno never considered his constructions as playful experiments or "gadgets". For all of his attempts at particularisation and individualisation were linked to the modem and modernist notions of truth, critique and utopia. All of these notions have been abandoned by postmodern writers and philosophers who tend to consider them as metaphysical remnants of a bygone age. What Rorty has to say about Hegel is particularly characteristic of the postmodern stance:

But Derrida does not want to comprehend Hegel's books; he wants to play with Hegel. He doesn't want to write a book about the nature of language; he wants to play with the texts which other people have thought they were writing about language (Rorty, 1982:96).

Like postmodern literature, postmodern philosophy of the Rortyan brand has long since abandoned the quest for truth. At the same time it has abandoned social critique and the utopian aspirations on which it thrives.

In this respect it is one-dimensional in Marcuse's sense. Unlike postmodern philosophies, Critical Theory declares its solidarity with some key concepts of metaphysics (Adomo, 1966:398) in order to assure the continuity of critique. It is constructivist in the modernist sense insofar as it rejects Hegel's postulate of identity ("Identitätsdenken"); however, its constructions - essayism, models, dialogues - are inspired by the quest for understanding, truth and critical 
knowledge and would be meaningless without it. In this respect, Critical Theory differs sharply from postmodern constructivism.

\section{Bibliography}

Adorno, Th W. 1966. Negative Dialektik. Frankfurt: Suhrkamp.

Adorno, Th. W. 1970. Asthetische Theorie. Frankfurt : Suhrkamp.

Balzac de, H. 1965. Le Comédie humaine vol. I. Paris : Seuil.

Balzac de, H. 1968. Les Paysans. Paris : Gallimard

Barth, J 1988. Lost in the Funhouse. New York, London : Doubleday, Anchor

Barthes, R. 1971. Sade, Fourier, Lyola. Paris : Seuil.

Calvino, I. 1979. Se una notte d'inverno un viaggiatore. Torino : Einaudi.

Chladenius, J.M. 1752. Allgemeine Geschichtswissenschaft. Leipzig : Duncker \& Humblot

Eco, U. 1980. Postille a Il nome della rosa (1983). In: Eco, U. Il nome della rosa. Milano : Bompiani. p. 507-533.

Eliot, G. 1985. Adam Bede. London: Penguin

Fowles, J 1992. The French Lieutenant's Woman. London : Picador.

Nietzsche, F. 1980. Die frohliche Wissenschaft. München : Hanser

Pirandello, L. 1985. Uno, nessuno e centomila. Milano : Mondadori.

Proust, M. 1954. A la recherche du temps perdu. Paris : Gallimard.

Robbe-Grillet, A. 1959. Dans le labyrinthe. Paris : Minuit.

Roche, M. 1966. Compact. Paris : UGE.

Rorty, R. 1982. Consequences of Pragmatism. Minneapolis : University of Minnesota Press.

Ryan, M. 1988. Postmodern Politics. In: Ryan, M. Theory, Culture and Society, vol. 5, no. 2-3 p. $559-576$

Sartre, J.-P. 1966 L'universel singulier. In: Kierkegaard vivant. Paris : Gallimard.

Sartre, J.-P. 1981. La Nausée. Paris : Gallimard

Smith, J.E. 1974. Hegel's Critique of Kant. In: Hegel and the Philosophy of History. Proceedings of the 1972 Hegel Society of America Conference, ed by J.J. O'Malley, K.W Algozin, F.G. Weiss. The Hague : Nijhoff. p. 109-128

Unamuno, M. 1978. Niebla. Madrid : Espasa Calpe

Verga, G. 1973. Introduzione a L'Amante di Gramigna. In. P. Pullega Leggere Verga. Antologia della critica verghiana. Bologna : Zanichelli. p. 360-361.

Vischer, F.Th. 1922. Der Traum Eine Studie zu der Schrif: Die Traumphantasie von Dr Johann Volkelt. In: Kritische Gänge Bd. 4. München : Meyer \& Jessen. p. 459-488. 